\title{
Hydrological Impacts of Climate Change and Land Use
}

\author{
František Petrovič $\mathbb{D}$
}

Citation: Petrovič, F. Hydrological Impacts of Climate Change and Land Use. Water 2021, 13, 799. https:// doi.org/10.3390/w13060799

Received: 24 February 2021

Accepted: 10 March 2021

Published: 15 March 2021

Publisher's Note: MDPI stays neutral with regard to jurisdictional claims in published maps and institutional affiliations.

Copyright: (C) 2021 by the author. Licensee MDPI, Basel, Switzerland. This article is an open access article distributed under the terms and conditions of the Creative Commons Attribution (CC BY) license (https:// creativecommons.org/licenses/by/ $4.0 /)$.
Department of Ecology and Environmental Sciences, Faculty of Natural Sciences, Constantine the Philosopher University in Nitra, 94901 Nitra, Slovakia; fpetrovic@ukf.sk

\begin{abstract}
Water is a basic, necessary condition for life. It is referred to as the main commodity of the 21st century. There are already many areas in the world where its deficiency causes the degradation of landscape components (soil, flora, fauna), leading to the abandonment of this landscape and a gradual deterioration into desert. Desertification can lead to poverty, health problems and loss of biodiversity. Such negative processes can be caused by human influence either directly or indirectly. Indirectly, the civilization has an impact on water as a result of climate change influenced by its activities. The matter of climate change is currently a very frequently discussed issue. Climate change on planet Earth has been ongoing in the past and continues to happen today. However, most alarming is the fact that change is currently happening much faster and with increasing intensity. For this reason, the issue of climate change is no longer perceived only as a possible future threat, but rather is considered as one of the crucial environmental problems of today.
\end{abstract}

Keywords: climate changes; land use/land cover (LULC) changes; hydrological impacts and modeling

Climate change is increasingly burdening water bodies. It is expected that in the coming years, the effects of climate change will intensify such phenomena as floods and droughts, as well as acidification of the oceans and rising sea levels. In response to these changes, there is a need to accept measures globally, across the whole Earth. Cities and regions are already adapting; using more sustainable natural solutions to reduce the impact of floods and using water in smarter, more sustainable ways that will allow us to cope with droughts in the future.

According to the European Environment Agency (EEA) report on Climate change, impacts and vulnerabilities in Europe, many regions in Europe are already facing more extreme floods and droughts [1]. Glaciers are melting, snow and ice cover is shrinking. Precipitation patterns are changing, in general the humid regions of Europe are becoming even wetter and the dry ones even more arid. At the same time, the frequency and intensity of climatic extremes is increasing, for example heat waves, torrential rains and droughts.

As a result of climate change, the average water temperature of rivers and lakes has also increased and the duration of the ice cover period has been shortened. These changes, together with higher river flows in winter and lower ones in summer, have a major impact on water quality and freshwater ecosystems. Some of these changes have increased the burden upon aquatic habitats, for example pollution. A lower flow rate due to lower precipitation leads to an increase in the concentration of pollutants, since less water is available to dilute the pollution.

The best way into the future is attempting identification of possible impacts that might occur and preempting them in advance. Among possibilities confirmed by a good experience with water retention in the landscape are the identification and protection of historical structures of the agricultural landscape (small mosaics) [2], the construction of green infrastructure, or even rationally solved land consolidation projects [3]. There are a number of innovative measures and approaches that have already been successfully tested and implemented in different regions of the Earth.

Therefore, this Special Issue (SI) of the Water journal is developed to bring out the knowledge on the combined effect of LULC and climate change on hydrological processes 
and water resources, including modeling approaches. Based on their research, all SI authors confirm the negative effects of climate change on hydrological processes.

Climate and land-use change are the two main driving forces that affect watershed hydrological processes. Separately assessing their impacts on hydrology is important for land-use planning and management of water resources. Climate is one of the main factors that influence surface runoff, especially in flooding periods. The soil water exhibits great fluctuation as shown by results of case studies from different regions of the world.

In China, in the Loess Plateau region, the authors [4] confirmed that, the evapotranspiration was more sensitive to land-use change than climate variability. A study for the region confirmed that, along the spatial distribution, it converted from land-use change to climate variability from northwest to southeast.

To prevent the ecosystem degradation and maintain the inherent ecological functions of rivers, quantitative assessment of the influence of climate variability and land-use change on hydrology is of great importance. Such evaluations can provide insight into the extent of land use/cover change on regional water balance and help to develop appropriate watershed management strategies.

The intensification of agricultural activity and the regime of water reservoirs are of great importance for the water regime of the area. This will be reflected in the entire basin. For example, the authors of the Beichuan River Basin in the northeast Tibetan Plateau [5] confirmed that climate change also enhanced the minimum streamflow in the whole river basin and advanced the occurrence of the daily minimum streamflow. Temperature change exerted greater influence on streamflow regime than wind speed change did in most situations, but the impact of wind speed on streamflow reflected the characteristics of accumulative effects, which may require more attention in the future, especially in large river basins. As for LULC, cropland expansion and reservoir operation were the primary reasons for streamflow reduction. Cropland expansion contributed more to annual mean streamflow change, using reservoir operation greatly altered monthly streamflow pattern and extreme streamflow. Reservoir regulation also postponed the timing of minimum streamflow and extended durations of average, high and low streamflow.

The overall decline of annual flow is due to the decline in the seasonal flows under combined scenarios. This could bring the reduced availability of water for crop production, which will be a chronic issue of subsistence agriculture. The possibility of surface water and groundwater reduction could also affect the availability of water resources in the catchment and further aggravate water stress in the downstream [6].

Some papers in the SI were focused on the impact of climate change on the change of groundwater regime [7] and subsequently on the change of hydrological properties of soils [8]. The authors [9] confirmed in the regions of Central Europe as well as in the Netherlands [10] significant shifts in runoff seasonality, coinciding with the timing of the air temperature rise, marked by earlier snow-melt, followed by a decline in spring flows and a prolonged period of low flows. The progressive built-up area-the impermeability of the landscape - can also have an indirect effect on the hydrological regime. Impermeable surfaces are introduced into the landscape, affecting the natural infiltration of water in the environment [11]. Apart from the construction of roads, the development of cities [12] currently has the greatest impact on the built-up areas. Urban development causes multiple water losses. As urban sprawl rises, space for unaffected infiltration and retention is increasingly limited. Historically functional anti-erosion measures to reduce unwanted water runoff and soil erosion also have a positive effect on the landscape's retention capacity [13].

Recently, the demand for longer water retention in the form of water reservoirs has been increasing. Therefore, it is important to identify suitable sites based on multiple factors including landscape properties. An example of such approach is the work [14], in sub-basins of the Nitra river (Slovakia). Partial river basins were examined for each of the existing and new reservoirs using a digital relief model. The area size, proportion of arable land, forestland and built-up area, degree of exposure to soil erosion and the volume of 
surface runoff have been used as parameters for comparisons. The result was a similarity evaluation of new sites potential issues in a regional context.

For all spatial designs or analyzes in the SI the authors used remote sensing data (analyzed by GIS methods), which appear to be important support decision tools for management at the landscape scale.

In the future, it is possible to refine the models of hydrological change to climate change. These will be projected from global to regional rates using GIS methods. These increase their detail with current data obtained by new remote sensing methods (such as LIDAR), while increasing the availability of detailed current satellite images for virtually all regions of the world (suitable data for assessing LULC changes).

Funding: This research received no external funding.

Conflicts of Interest: The author declares no conflict of interest.

\section{References}

1. Climate Change Poses Increasingly Severe Risks for Ecosystems, Human Health and the Economy in Europe. Available online: https://www.eea.europa.eu/highlights/climate-change-poses-increasingly-severe (accessed on 18 February 2021).

2. Špulerová, J.; Petrovič, F.; Mederly, P.; Mojses, M.; Izakovičová, Z. Contribution of traditional farming to ecosystem services provision: Case studies from Slovakia. Land 2018, 7, 74. [CrossRef]

3. Muchová, Z.; Raškovič, V. Fragmentation of land ownership in Slovakia: Evolution, context, analysis and possible solutions. Land Use Policy 2020, 95, 104644. [CrossRef]

4. Kang, Y.; Gao, J.; Shao, H.; Zhang, Y. Quantitative analysis of hydrological responses to climate variability and land-use change in the hilly-gully region of the Loess Plateau, China. Water 2020, 12, 82. [CrossRef]

5. Liu, Z.; Cuo, L.; Li, Q.; Liu, X.; Ma, X.; Liang, L.; Ding, J. Impacts of climate change and land use/cover change on streamflow in Beichuan river basin in Qinghai province, China. Water 2020, 12, 1198. [CrossRef]

6. Dibaba, W.T.; Demissie, T.A.; Miegel, K. Watershed hydrological response to combined land use/land cover and climate change in highland Ethiopia: Finchaa catchment. Water 2020, 12, 1801. [CrossRef]

7. Štefunková, Z.; Macura, V.; Škrinár, A.; Majorošová, M.; Doláková, G.; Halaj, P.; Petrová, T. Evaluation of the methodology to assess the influence of hydraulic characteristics on habitat quality. Water 2020, 12, 1131. [CrossRef]

8. Igaz, D.; Aydin, E.; Šinkovičová, M.; Šimanský, V.; Tall, A.; Horák, J. Laser diffraction as an innovative alternative to standard pipette method for determination of soil texture classes in Central Europe. Water 2020, 12, 1232. [CrossRef]

9. Langhammer, J.; Bernsteinová, J. Which aspects of hydrological regime in mid-latitude Montane basins are affected by climate change? Water 2020, 12, 2279. [CrossRef]

10. Van Huijgevoort, M.H.J.; Voortman, B.R.; Rijpkema, S.; Nijhuis, K.H.S.; Witte, J.P.M. Influence of climate and land use change on the groundwater system of the Veluwe, The Netherlands: A historical and future perspective. Water 2020, 12, 2866. [CrossRef]

11. Jandová, V.; Bucková, M.; Hegrová, J.; Dostál, I.; Huzlík, J.; Effenberger, K.; Ličbinský, R. The relationship among precipitation, application of salt in winter road maintenance and the quality of waterways and soil around motorway. Water 2020, 12, 2206. [CrossRef]

12. Lepeška, T.; Wojkowski, J.; Wałęga, A.; Młyński, D.; Artur Radecki-Pawlik, A.; Olah, B. Urbanization-Its hidden impact on water losses: Prądnik river basin, lesser Poland. Water 2020, 12, 1958. [CrossRef]

13. Krnáčová, Z.; Kenderessy, P.; Juraj Hreško, J.; Kubínsky, D.; Dobrovodská, M. Assessment of landscape retention water capacity and hydrological balance in traditional agricultural landscape (model area Liptovská Teplička settlements, Slovakia). Water 2020, 12, 3591. [CrossRef]

14. Gacko, I.; Muchová, Z.; Jurík, L'.; Šinka, K.; Fabian, L.; Petrovič, F. Decision making methods to optimize new dam site selections on the Nitra river. Water 2020, 12, 2042. [CrossRef] 